\title{
PERANAN PERENCANAAN DAN PROSES PRODUKSI TERHADAP KELANCARAN PENGIRIMAN BARANG DI PT TEAM METAL INDONESIA (TMI)
}

\section{THE ROLE OF PLANNING AND PRODUCTION PROCESS ON TRANSMISSION OF DELIVERY OF GOODS IN PT TEAM METAL INDONESIA (TMI)}

\author{
Rejeki Bangun ${ }^{1}$, Nasruji ${ }^{2}$ \\ ${ }^{1}$ Program Studi Magister Manajemen Program Pascasarjana Universitas Riau Kepulauan \\ ${ }^{2}$ FKIP Universitas Riau Kepulauan \\ rejeki@teammetal.com
}

\begin{abstract}
Abstrak
Penelitian ini bertujuan untuk mengetahui peranan perencanaan dan proses produksi terhadap kelancaran pengiriman barang di PT Team Metal Indonesia (TMI). Penelitian ini merupakan penelitian kualitatif, dengan metode analisa deskriptif mengenai seberapa jauh peranan perencanaan dan proses produksi terhadap kelancaran pengiriman barang di PT Team Metal Indonesia (TMI).Kesimpulan penelitian ini adalah perencanaan lebih berpengaruh terhadap kelancaran pengiriman barang di PT Team Metal Indonesia sebesar $19.50 \%$ sedangkan proses produksi berpengaruh sebesar $14.15 \%$

Kata kunci: Perencanaan, Proses Produksi, Pengiriman.

Abstract

This research aims to get information that planning, production process towarddelivery performance in PT Team Metal Indonesia(TMI). This research categorizied as qualitative research with descriptive analysis to describe the influence of planning, production process toward delivery performance in PT Team Metal Indonesia(TMI). Result of this research that Planning contribution is about $19.50 \%$ towards delivery performance and production process contribution is about $14.15 \%$.
\end{abstract}

Keywords: Planning , Production Process, DeliveryPerformance

\section{PENDAHULUAN}

Pulau Batam merupakan kawasan industri dan perdagangan berbasis Internasional, pulau Batam memiliki sedikitnya 20 kawasan industri yang didominasi oleh jenis perusahaan manufacturing dan selebihnya merupakan perusahaan alih kapal (shipyard), trading company dan pariwisata. Salah satu alasan banyaknya industri yang berdiri di Batam ini dikarenakan letak Batam yang strategis karena berdekatan dengan Singapura dan Malaysia. Selain itu, upah pekerja Batam yang relatif rendah dibandingkan tempat lain karena banyaknya pendatang dari berbagai daerah, hal tersebut juga merupakan salah satu alasan banyak investor yang mendirikan industri di kota Batam ini. 
Pulau Batam juga merupakan kota impian masyarakat Indonesia untuk mencari pekerjaan. Adapun hal yang membuat kota Batam diminati oleh para pekerja adalah dikarenakan letaknya yang strategis, kebijakan dan perlakuan khusus di bidang perindustrian seperti FTZ sehingga dapat menciptakan suatu perkembangan ekonomi yang pesat. Hal ini menjadi suatu daya tarik bagi investor untuk menanamkan modalnya pada kota Batam ini baik di dalam negeri maupun di luar negeri.

PT. Team - Metal Indonesia (TMI) merupakan salah satu perusahaan yang menanam modal di Kota Batam ini yang terletak di Kawasan Bintang Industrial Park II Tanjung Uncang, Kota Batam adalah perusahaan multinasional dari Singapura dibawah kepemilikan PT. Team Metal (S) yang bergerak dalam bidang industri pembuatan Komponen Mekanikal, Electrical, dan Sub Assy Modular melalui berbagai proses menggunakan mesin. Keberadaan perusahaan tersebut diharapkan dapat memberi sumbangsih yang berarti terhadap peningkatan pertumbuhan perekonomian dan pembangunan daerah melalui peningkatan kesempatan kerja dan pendapatan pemerintah setempat, khususnya daerah Kota Batam dan Kepulauan Riau umumnya yang salah satunya dengan cara perencanaan dan proses produksi yang benar dan pengiriman barang yang tepat waktu (delivery on time).

Perencanaan adalah fungsi manajemen yang paling pokok dan sangat luas meliputi perkiraan dan perhitungan mengenai kegiatan yang akan dilaksanakan pada waktu yang akan datang mengikuti suatu urutan tertentu. Perencanaan merupakan salah satu sarana manajemen untuk mencapai tujuan yang telah ditetapkan karena itu setiap tingkat manajemen dalam organisasi sangatmembutuhkan aktivitas perencanaan. Tujuan perencanaan harus tegas, jelas dan mudah dimengerti. Seringkali perencanaan harus mengalami perubahan, oleh karena itu perencanaan harus besifat luwes dan terbuka untuk dapat dirubah bila diperlukan.

Sifat luwes ini mengakibatkan pelaksanaan kegiatannya harus dimonitor dan dikendalikan terus menerus yang disesuaikan dengan kondisi yang ada namun perencanaan harus tetap pada tujuan yang ditetapkan dalam hal ini adalah pengiriman barang yang tepat waktu.

Menurut Siagian (2008:41)Istilah perencanaan merupakan pengambilan keputusan sekarang tentang hal hal yang akan dikerjakan di masa yang akan datang. 
Proses adalah cara, metode dan teknik bagaimana sesungguhnya sumber-sumber (tenaga kerja, mesin, bahan dan dana) yang ada di ubah untuk memperoleh suatu hasil. Sedangkan produksi seperti kita ketahui adalah kegiatan untuk menciptakan atau menambah kegunaan suatu barang atau jasa.

Menurut Assauri (2008) proses produksi dapat diartikan sebagai suatu cara, metode dan teknik untuk menciptakan atau menambah kegunaan suatu barang atau jasa dengan menggunakan sumber sumber yang ada.

Menurut Pardede (2007) ketepatan pengiriman barang sangat berkaitan dengan standard waktu yang telah ditentukan (predetermined time standard) membagi pekerjaan menjadi elemen dasar yang kecil yang telah memiliki waktu tertentu. Untuk memperkirakan waktu untuk sebuah pekerjaan tertentu, faktor waktu bagi setiap elemen dasar dari pekerjaan dijumlahkan.

\section{Tujuan Penelitian}

1. Mengetahui pengaruh perencanaan produksi secara signifikan terhadap kelancaran pengiriman barang di PT. Team Metal Indonesia (TMI)?

2. Mengetahui pengaruh proses produksi secara signifikan terhadap kelancaran pengiriman barang di PT. Team Metal Indonesia (TMI)?

\section{Perencanaan}

Perencanaan adalah fungsi manajemen yang paling pokok dan sangat luas meliputi perkiraan dan perhitungan mengenai kegiatan yang akan dilaksanakan pada waktu yang akan datang mengikuti suatu urutan tertentu. Perencanaan merupakan salah satu sarana manajemen untuk mencapai tujuan yang telah ditetapkan karena itu setiap tingkat manajemen dalam organisasi sangatmembutuhkan aktivitas perencanaan. Tujuan perencanaan harus tegas, jelas dan mudah dimengerti. Seringkali perencanaan harus mengalami perubahan, oleh karena itu perencanaan harus besifat luwes dan terbuka untuk dapat dirubah bila diperlukan.

Menurut Siagian (2008:41) istilah perencanaan merupakan pengambilan keputusan sekarang tentang hal hal yang akan dikerjakan di masa yang akan datang. 


\section{Proses Produksi}

Proses produksi dapat diartikan sebagai suatu cara, metode dan teknik untuk menciptakan atau menambah kegunaan suatu barang atau jasa dengan menggunakan sumber sumber yang ada (Assauri: 2008).

Seperti kita ketahui bahwa cara, metode dan teknik menghasilkan produk cukup banyak, maka proses produksi dalam hal ini sangat banyak macamnya. Walaupun proses produksi ini sangat banyak, tetapi secara ekstrem dapat di bedakan menjadi dua, yaitu proses produksi yang terus menerus (continuos processes) dan proses produksi yang terputus putus (intermittent processes).

\section{Pengiriman Barang}

Sebagai tambahan bagi pengalaman masa lalu dari studi waktu, standard produksi dapat ditetapkan dengan menggunakan waktu yang telah ditentukan. Standard waktu yang telah ditentukan (predetermined time standard) membagi pekerjaan menjadi elemen dasar yang kecil yang telah memiliki waktu tertentu. Untuk memperkirakan waktu untuk sebuah pekerjaan tertentu, faktor waktu bagi setiap elemen dasar dari pekerjaan dijumlahkan. Standar waktu yang telah di tentukan yang paling umum adalah metode pengukuran waktu. Maka kita dapat mengestimasi jadwal pengiriman barang dari pengukuran waktu tersebut (Pardede: 2007).

\section{METODOLOGI}

\section{Rancangan Penelitian}

Metode yang digunakan dalam penelitain ini adalah metode analisa deskriptif. Analisa deskriptif menurut Jogiyanto (2003:12), adalah suatu metode yang mencoba menggambarkan suatu fenomena apa adanya tentang suatu variabel pada saat penelitian dilakukan dan disertai dengan pengukuran-pengukuran atau penilaian data data yang di kumpulkan, kemudian di bahas dan di analisa sehingga di tarik suatu kesimpulan.

Untuk menjawab rumusan masalah mengenai seberapa jauh peranan perencanaan dan proses produksi terhadap kelancaran pengiriman barang di PT. Team Metal Indonesia (TMI), maka penulis membuat persentase perbandingan delivery performance dari tahun 2007 sampai 2010. 


\section{Prosedur Pengumpulan Data}

Penulis mengumpulkan data yang dapat dipercaya dan relevan serta sesuai dengan masalah yang di bahas. Data tersebuat akan menunjang keperluan analisis guna tercapainya tujuan penelitian. Penulis telah mengumpulkan bebagai macam data yang diperlukan melalui cara cara sebagi berikut:

1. Penelitian kepustakaan (library research)

Penelitian ini merupakan penelitian yang dilakukan untuk memperoleh landasan teori yang berkaitan dengan masalah yang akan di bahas melalui buku-buku referensi serta mempelajari teori-teori yang ada hubungannya dengan penulisan skripsi ini.

2. Penelitian lapangan (field research)

Penulis melakukan penelitian lapangan di PT. Team Metal Indonesia (TMI), dimana penulis mengamati secara langsung perencanaan dan proses produksi di lakukan.

\section{Teknik Analisis Data}

Analisis data dilakukan adalah metode analisa deskriptif.

\section{PEMBAHASAN}

\section{Sejarah Singkat dan Operasional PT Team Metal Indonesia(TMI)}

PT. Team Metal Indonesia (TMI) merupakan salah satu perusahaan di Pulau Batam yang bergerak dalam bidang industri pembuatan komponen Mekanikal, Electrical, dan Sub Assy Modular melalui berbagai proses menggunakan mesin. Yang berdiri pada tahun 1997 dan ditempatkan di Muka Kuning dengan luas paberik 2000m², kemudian pada tahun 1999 PT. Team Metal Indonesia memindahkan kegiatan industrialnya ke Jl.Brigjen Katamso No.78, Bintang Industrial Park II Tanjung Uncang, Kota Batam, Indonesia, Telp. (+62778) 393088, Fax. (+62778) 393182 dengan pengembangan luas pabrik menjadi 6000m².

PT. Team Metal Indonesia mendapatkan sertifikat ISO 9002 pada tahun 2000 kemudian di tahun 2002 berhasil mengabungkan departemen Die Casting sebagai tambahan fasilitas perusahaan yang dapat menghasilkan produk casting. Untuk menunjang kelancaran kegiatan proses produksi perusahaan maka pada tahun 2003 PT. Team Metal Indonesia mengimplementasikan system ERP. 
Perusahaan ini merupakan cabang dari Team Metal (S) Pte.Ltd yang berkedudukan di Singapura yang beralamatkan di 31 Kaki Bukit View, Kaki Bukit Tech Park II, Singapore 415-964, Telp. (+65) 6742-3088, Fax. (+65) 6742-3266, email address: info@teammetal.com dan website: www.teammetal.com serta memiliki cabang industrial di China pada tahun 2004 yang berkedudukan di Suzhou, Team Metal (Suzhou) yang beralamat di No.9 Dong Fu Road, 33\# Dong Jing Industrial Square Suzhou Industrial Park, PRC 215126 China

Seperti yang sudah di jelaskan bahwa perencanaan meliputi perkiraan dan perhitungan mengenai kegiatan yang akan dilaksanakan pada waktu yang akan datang mengikuti suatu urutan tertentu.

Berikut ini adalah Planning process flow di PT Team Metal Indonesia:

a) Production Controller menerima Sales Order dari departemen logistik, media penerimaanya biasanya berupa :

1. Master work order plan

2. Email

3. Sales order report

b) Production Controller selanjutnya mengkaji ketersediaan sumber daya seperti mesin, material (bahan baku), tooling dan sumber daya lainnya untuk memproduksi barang dan memastikan proses produksi dapat dilaksanakan tepat waktu dan dapat mencapai target pengiriman barang yang telah di tentukan di Sales Order. Media dan alat bantu yang di gunakan adalah:

1. Control Plan / Process Flow Management Plan (PFMP)

2. Material status

3. Tooling status

4. Tooling control procedure.

c) Selanjutnya Production planner melakukan perencanaan produksi dan menyerahkannya kepada Planning Head Of Deparment. Pada tahap ini biasanya di dibantu dengan media:

1. Production planning log

2. Production Planning spreadsheet 


\section{Travel Tag}

4. Orion MPS worksheet.

d) Langkah selanjutnya Production Clerk melakukan Work order generation ke produksi dengan media dan bantuan:

1. Orion work order

2. Travel Tag

e) Selanjutnya adalah proses pelaksanaan produksi dalam hal ini banyak yang terlibat di dalamnya seperti Production staff, Inprocess quality control dan QA staff. Media dan bantuan yang di pakai adalah:

1. Production operation quality procedure

2. Process inspection quality procedure

3. Outgoing inspection quality procedure

f) Material handler menerima production output dari produksi dan seluruh produksi harus menyelesaikanya sesuai dengan tanggal yang telah di tentukan oleh Planner, Material Handler harus memastikan kuantitas sesuai dengan Production work order yang di buat oleh Production clerk dan melaporkannya kepada Planning department. Apabila ada proses tambahan maka production planner harus menerbitkan kembali work order yang baru, ini dapat di lakukan sampai pekerjaan produksi selesai dengan baik dan sampai di cek dan di setujui oleh QA departemen. Media yang di pakai adalah:

1. Semi and finished parts identification

2. Work order

3. Travel tag

g) Pada tahap akhir production controller me-reviewoutput atau kuantiti dan melaporkannya kepada departemen logistik. Production controller harus memastikan kecocokan dokumen seperti work order, travel tag dan ini akan sangat membantu di dalam proses pengepakan/packing, penyimpanan (storing) dan pengiriman (delivery). 
Pada tahap akhir ini dokumen dan media yang di pakai adalah:

1. Work order

2. Production Planning work sheet

3. Incoming record

4. Outgoing record

5. Production transaction slip

6. Store stock card

Berikut ini adalah Production process flow/production operation di PT Team Metal Indonesia:

a) Production Superintendent menerima Work order dari Production controller baik secara manual maupun di Orion system, kemudian mengevaluasi tanggal selesai waktu produksi yang telah di tetapkan dan juga memastikan kesiapan machine and manpower capacities dan material. Production Superintendent juga harus memahami kuantiti yang harus di produksi, cycle time, dan total waktu yang di butuhkan oleh produksi untuk memproduksi barang tersebut. Pada tahap ini media dan alat bantu yang digunakan adalah:

1. Work order manual

2. Orion system

3. Travel tag

4. Production control and planning procedure

b) Production Superintendent harus mengevaluasi sebelum mendistribusikan pekerjaan tersebut ke production supervisor. Evaluasi juga harus meliputi kemungkinan kendala kendala yang akan di hadapi di kemudian hari. Pada tahap ini media yang di gunakan adalah:

1. Control plan/PFMP

2. Autolathe work instruction

3. Milling work instruction

4. SOD/Assy work instruction

5. Plating work instruction 


\section{Chuckerlathe work instruction}

c) Production supervisor menerima work order dari production superintendent, dan production supervisor harus mengkoordinasikan dan menginstruksikan team leader tentang pekerjaan yang akan di lakukan termasuk kesiapan semua sumber daya. Media dan alat bantu yang di gunakan pada tahap ini adalah:

1. Machine profile

2. Production planning log book

3. Production planning spreadsheet

d) Team leader menugaskan tehnisi produksi untuk pergantian set up / (change setting) dari produk yang lama ke produk yang baru, pada tahap ini set up harus sesuai dengan set-up procedure. Dan ketika set-up telah selesai di lakukan work order untuk tehnisi produksi dan selanjutnya melakukan hand over ke bagian produksi. Pada tahap ini media yang digunakan adalah :

1. Machining profile

2. Tool control procedure

3. Work order for Technician

e) Pekerjaan yang harus di lakukan oleh produksi harus berdasarkan instruksi kerja dan sesuai dengan permintaan. Operator produksi, dan Line leader harus fokus pada kualitas dan output. Pada proses produksi IPQCharus melakukan audit kualitas di area produksi sebelum barang tersebut di kirim ke proses berikutnya. Media yang di gunakan pada tahap ini adalah :

1. IPQC inpection

2. Daily production performance report

f) Langkah terakhir adalah follow up action dan feedback, pada tahap akhir ini pihak yang terlibat adalah production manager, production controller, superintendent, HOD/Supervisor, team leader dan production engineer. Biasanya di lakukan dengan rapat harian dan mingguan di sini akan dibahas efisiensi produksi, penggunaan mesin, kapasitas mesin, production performance, serta kedala apa saja yang di hadapi dan di berikan solusi yang tepat untuk permasalahan yang di temukan, di sini juga akan 
dilakuakn corrective action dan improvement plan untuk produksi selanjutnya. Media dan alat bantu pada tahap ini adalah:

1. Production efficiency and machine capacity utilization

2. Production forecast

3. Quality and improvement

4. Production control and planning procedure

5. Minutes of meeting.

Sepeti yang sudah di jelaskan bahwa delivery performance PT Team Metal Indonesia mengalami perubahan dari tahun ke tahun dan juga tidak menunjukkan performa yang baik.

Performa pengiriman terbaik PT Team Metal Indonesia terjadi pada tahun 2009 yaitu sebesar $71.03 \%$.

Untuk melihat dan menganalisa seberapa besar peranan perencanaan dan proses produksi berpengaruh terhadap ketepatan pengiriman barang di PT Team Metal Indonesia maka berikut ini penulis menampilkan tabel Summary deliveryperformance PT Team Metal dari tahun 2007 sampai dengan 2010 dan akan mengalisa tiap tahunnya.

\section{Tabel 1}

Kontribusi Perencanaan dan Prosess Produksi 2007 s/d 2010

\begin{tabular}{llll}
\hline Tahun & Perencanaan & Proses Produksi & Lain Lain \\
\hline 2007 & $19.50 \%$ & $14.15 \%$ & $4.20 \%$ \\
2008 & $17.80 \%$ & $13.75 \%$ & $8.69 \%$ \\
2009 & $10.93 \%$ & $10.00 \%$ & $8.04 \%$ \\
2010 & $11.20 \%$ & $8.60 \%$ & $10.92 \%$ \\
\hline
\end{tabular}

Sumber : Data Sekunder PT Team Metal Indonesia(diolah)

Dari Tabel 1 di atas dapat dilihat bahwa perencanaan lebih berpengaruh terhada pengiriman barang apabila di bandingkan dengan proses produksi. 
Perencanaan memberikan kontribusi paling tinggi sebesar 19.50\% pada tahun 2007 sedangkan proses produksi memberikan kontribusi paling tinggi sebesar $14.15 \%$ padah tahun 2007.

Perencanaan memberikan kontribusi terendah 10.93\% pada tahun 2009 sedangkan proses produksi memberikan kontribusi terendah 8.60\% padah tahun 2010.

Tabel 2

Summary Kontribusi Perencanaan, Prosess Produksi 2007 s/d 2010

\begin{tabular}{llllll}
\hline Tahun & 2007 & 2008 & 2009 & 2010 & Average \\
\hline Perencanaan : & & & & & \\
Short Lead Time & $5.50 \%$ & $9.10 \%$ & $3.10 \%$ & $4.40 \%$ & $5.53 \%$ \\
Planning Delay/Over Qty & $8.25 \%$ & $5.40 \%$ & $3.30 \%$ & $3.30 \%$ & $5.06 \%$ \\
Poor Arragement & $5.75 \%$ & $3.30 \%$ & $4.53 \%$ & $3.50 \%$ & $4.27 \%$ \\
Proses Produksi : & & & & & \\
Parts Rejected & $3.50 \%$ & $3.75 \%$ & $3.10 \%$ & $2.65 \%$ & $3.25 \%$ \\
Missing Process/Rework & $2.50 \%$ & $2.45 \%$ & $3.40 \%$ & $2.35 \%$ & $2.68 \%$ \\
Set-up Delay & $8.15 \%$ & $7.55 \%$ & $3.50 \%$ & $3.60 \%$ & $5.70 \%$ \\
Lain-Lain : & & & & & \\
Machine Break Down & $2.10 \%$ & $3.85 \%$ & $3.10 \%$ & $1.10 \%$ & $2.54 \%$ \\
Supplier Delay & $1.10 \%$ & $2.30 \%$ & $2.10 \%$ & $2.10 \%$ & $1.90 \%$ \\
Material Defects & $1.00 \%$ & $1.54 \%$ & $0.54 \%$ & $0.70 \%$ & $0.95 \%$ \\
Capacity constraint & $0.00 \%$ & $1.00 \%$ & $2.30 \%$ & $1.80 \%$ & $1.28 \%$ \\
Orion system & $0.00 \%$ & $0.00 \%$ & $0.00 \%$ & $5.22 \%$ & $1.31 \%$ \\
\hline
\end{tabular}

Sumber : Data Sekunder PT Team Metal Indonesia (diolah)

Pada Tabel 2 dapat dilihat bahwa dari sisi perencanaan short lead time memberikan kontribusi yang besar terhadap keterlambatan pengiriman barang yaitu rata rata sebesar 5.53\% , Planning delay/over qty sebesar 5.06\% dan 4.27\% karena poor arrangement. 
Dari sisi Proses produksi Set-up delay memberikan kontribusi terbesar terhadap keterlambatan pengiriman barang yaitu rata rata sebesar 5.70\%, Part reject sebesar 3.25\% dan missing process sebesar $2.68 \%$.

\section{KESIMPULAN DAN SARAN}

\section{Kesimpulan}

1. Berdasarkan penelitian yang dilakukan penulis bahwa peranan perencanaan dan proses produksi berpengaruh terhadap kelancaran pengiriman barang di PT Team Metal Indonesia (TMI).

2. Peranan perencanaan lebih dominan bila dibandingkan dengan proses produksi karena dari tahun ke tahun memberikan persentase yang lebih besar yaitu 19.05\% pada tahun 2007.

3. Selain perencanaan dan proses produksi , juga di pengaruhi oleh faktor faktor lain seperti mesin rusak,kapasitas mesin yang terbatas serta pengimplementasian system baru yang mana process owner sendiri belum siap untuk menjalankannya.

\section{Saran}

1. Dari penelitian yang dilakukan ini dapat di buktikan bahwa kegagalan pengiriman barang mayoritas disebabkan oleh perencanaan dan proses produksi yang kurang baik. Untuk itu penulis menyarankan kepada Manajemen PT Team Metal Indonesia (TMI) untuk lebih memperbaiki kondisi ini dengan melakukan negoisasi dengan pelanggan untuk mendapatkan informasi tentang permintaan barangagar lebih awal dan akurat sehingga dapat meningkatkan kelancaran pengiriman barang yang berhubungan langsung dengan short lead time.

2. Diharapkan kepada Manajemen PT Team Metal Indonesia (TMI) dapat meng upgrade untuk level technician misalnya dengan melakukan pelatihan baik secara internal dan eksternal sehingga keterlambatan pengiriman barang karena set-up delay dapat di minimalisasi.

3. Diharapkan kepada Manajemen PT Team Metal Indonesia (TMI) dapat mengimplementasikan system Just In Time (JIT) sehingga over produced dapat di 
hindarkan dan juga dapat menekan biaya produksi dan mencoba untuk berdiskusi dengan pelanggan untuk mengurangi safety stock di dalam sistem produksi.

4. Diharapkan kepada Manajemen PT Team Metal Indonesia (TMI) dapat memberdayakan production coordinator dengan baik sehingga waiting time dapat dihindarkan atau diminimalisasi dan arrangement dapat dilakuakan dengan lebih baik lagi.

\section{REFERENSI}

Elwood S. Buffa \& Rakesh (1996). Modern Production/Operation Management.Jakarta

Barat. Penerbit Binapura aksara

Hartono Jayanto. (2003). Metode Penelitian Bisnis,Salah Kaprah dan Pengalaman

Pengalaman. Yogyakarta. BPFE UGM.

Hasibuan Malayu. (1999). Organisasi dan Motivasi. Jakarta . Penerbit Bumi Aksara. Jay Heizer \& Barry Render. (2006).Operation Management . Penerbit Salemba Empat Pardede , Pontas M (2007). Manajemen Operasi dan Produksi.Yogyakarta. Andi Sofjan assquri (2008) Manajemen Produksi dan Operasi edisi revisi. Jakarta : FE UI Teguh Baroto. (2002) Perencanaan dan Pengendalian Produksi. Jakarta: Ghalia Indonesia Vincent Gasperzt (2000). Manajemen Produktivitas Total, Strategi Peningkatan Produktivitas Bisnis Global Jakarta : Gramedia Pustaka Umum. www.teammetal.com 